\title{
PENGARUH NAUNGAN TERHADAP PERTUMBUHAN SEMAI MAKILA (Litsea angulata)
}

\author{
INFLUENCE SHADE ON THE GROWTH OF THE SEEDLING OF MAKILA (Litsea \\ angulata)
}

\author{
Edom Bayau
}

\author{
Jurusan Kehutanan Fakultas Pertanian Universitas Pattimura Ambon \\ Jl. Ir.M.Putuhena Kampus Poka Ambon 97237 \\ Penulis korespondensi email : edomforester@ gmail.com
}

\begin{tabular}{|l|l|}
\hline Diterima : 20 Februari 2018 & Disetujui : 7 Maret 2018 \\
\hline
\end{tabular}

\section{Intisari}

Makila (Litsea angulata) merupakan jenis kayu yang komersial dan sangat diminati oleh banyak orang karena kualitasnya yang baik dan juga bisa digunakan sebagai obat dalam menyembuhkan penyakit rematik sehingga harus mendapakan perhatian penting. budidaya/ memperbanyak makila dapat dilakukan dengan cara yang cepat yaitu melalui persemaian di lapangan. dalam persemaian perlu juga memperhatikan hal-hal yang berpengaruh terhadap makila, salah satunya adalah intensitas cahaya matahari berhubungan dengan pertumbuhan semai makila. Penelitian ini dilakukan di lokasi ruma kaca Fakultas Pertanian Universitas Pattimura yang berlagsung bulan september sampai dengan bulan November 2014 dengan tujuan untuk mengetahui pertumbuhan semai makila (litsea angulata) untuk mengetahui berapa persen naungan yang baik bagi pertumbuhan semai makila (Litsea angulata). Rancangan percobaan yang digunakan adalah Rancangan Acak Lengkap (RAL) dengan 5 (lima) taraf perlakuan. Nilai rata-rata ada penelitian adalah semai tanpa menggunakan naungan 0,143 , naungan 30 persen 0,167 , naungan 50 persen 0,20 , naungan 65 persen 0,453 , dan naungan 75 persen 0,210. Hasil penelitian menunjukan bahwa semai Makila (litsea angulata) adalah jenis yang toleransi dengan naungan atau dengan kata lain bahwa jenis makila mampu bertumbuh pada tempat yang terbuka maupun tempat yang ternaung karena setiap semai dapat ditanam jika Memiliki Indeks Mutu bibi 0,09.

\section{Kata kunci : Pengaruh Naungan, semai makila}

\begin{abstract}
Makila (Litsea angulata) is a type of commercial timber and is very attractive to many people because of good quality and can also be used as a medicine in curing rheumatic diseases should be assigned the paramount concern. cultivation / reproduce makila can be done in a fast way is through the nursery in the field. in nurseries should also pay attention to things that affect makila, one of which is related to the intensity of sunlight makila seedling growth. The research conducted at the location of the greenhouse Faculty of Agriculture, University of Pattimura which take place september until november 2014 with the aim to determine the seedling growth makila (Litsea angulata) to determine what percentage of shade is good for seedling growth makila (Litsea angulata). The experimental design used was completely randomized design (CRD) with 5 (five) treatments, the seedlings without using Shade, Shade 30 percent, 50 percent Shade, Shade 65 percent, and Shade 75 percent. The results showed that the seedling Makila (Litsea angulata) is a kind of tolerance with all shade or kind makila able to grow in places that are open and shaded place.
\end{abstract}

Keywords: Influence Shade, makila seedling

DOI:10.30598/jhppk.2017.1.3.262 


\section{PENDAHULUAN}

Hutan sangat memegang peranan penting bagi makhluk hidup terutama manusia baik secara langsung maupun tidak langsung. pengelolaan hutan harus dilaksanakan secara lestari dengan menggunakan prinsip-prinsip kelestarian, untuk itu diperlukan data dan informasi mengenai sumberdaya hutan yang dapat dperoleh melalui kegiatan inventarisasi.

berdasarkan undang-undang nomor 41 tahun 1999 tentang kehutanan, yang dimaksud dengan hutan ialah suatu kesatuan ekosisitem berupa hamparan lahan berisi sumberdaya alam hayati yang didominasi pepohonan dalam persekutuan alam dan lingkunganya, yang satu dengan lainya tidak dapat dipisahkan. ( Spurr 1973), hutan merupakan sekumpulan pohon-pohon atau tumbuhan berkayu lainnya dan pada kerapatan dan luas tertentu mampuh menciptakan iklim setempat seta keadaan ekologis berbeda dengan diluarnya.

Separuh dari hutan yang ada dimuka bumi tergolong sebagai hutan tropik. Hutan-hutan itu sangat beranekaragam baik tipe, komposisi, maupun strukturnya. semua terjadi karena adanya variasi kondisi iklim dan tanah disetiap wilayah. Pada kondisi iklim yang berbeda-beda, akan dijumpai hutan dengan komposisi jenis vegetasi yang berbeda pula. masing-masing pohon yang menyusun tegakan hutan tersebut menghendaki persyaratan tempat tumbuh tertentu. Jika tempat tumbuhnya sesuai, pohon-pohon mampuh bersaing dan beradaptasi terhadap kondisi lingkungan tempat tumbuhnya, maka dominasi suatu jenis pohon akan muncul pada tempat tumbuh sehingga akan menjadi ciri dominasi dari tegakan.

Kayu Makila (Litsea angulata) merupakan salah satu jenis dari sekian banyak jenis flora berbungan yang ada di indonesia dan merupakan jenis yang secara alami tumbuh di kawasan indonesia khususnya di Sumatera, Jawa, Sunda, Kalimantan dan Maluku.

Kayu Makila (Litsea angulata) oleh masyarakat Maluku banyak dimanfaatkan untuk bahan kontruksi ringan sementara itu dengan meningkatnya jumlah penduduk, konversi lahan hutan semakin meluas sehingga di habitat alaminya kayu Makila (L. angulata) mulai mengalami penurunan populasi seperti yang terjadi pada Provinsi Maluku. untuk tindakan penyalamatan terhadap keberadaan kayu Makila (L. angulata) 
maka pengetahuan mengenai jenis ini penting untuk dipelajari karena untuk budidaya jenis ini hampir tidak ada sama sekali. Jenis makila (Litsea angulata) yang merupakan tanaman jenis endemik Maluku ini, dalam upaya memperbanyak/budidaya jenis ini, maka perlu mempelajari yaitu faktor-faktor yang mempengaruhi pertumbuhan. diantaranya faktor-faktor yang mempengaruhi pertumbuhan tanaman salah satunya adalah cahaya. Kebutuhan cahaya untuk masing-masing jenis tanaman berbeda, terutama pada pertumbuhan semai. dengan kata lain ada jenis yang toleran dan ada yang intoleran. untuk itu dengan megetahui seberapa besar naungan yang dibutuhkan untuk pertumbuhan semai makila (Litsea angulata) perlu dilakukan penelitian, selain itu di alam semai makila tumbuh dibawa pohon induk yang berada pada naungan yang berat Berdasarkan uraian diatas penulis tertarik untuk melakukan penelitian dengan judul "Pengaruh Naungan Terhadap Pertumbuhan Semai Makila (Litsea Angulata)"

\section{METODE PENELITIAN}

\section{Lokasi dan Waktu Penelitian}

Penelitian ini dilaksanakan dilokasi ruma kaca Fakultas Pertanian Universitas Pattimura. Penelitian dilaksanakan pada bulan September sampai bulan November 2014.

\section{Alat dan Bahan Penelitian}

Peralatan yang digunakan dalam penelitian ini antara lain : Mistar ukur, Alat tulis, Jangka sorong, Tali sheet, Camera, Oven, Decicator, Timbangan analitik, Gergaji, Paku, Gunting pangkas, Martil, Gelas Ukur. Sedangkan bahan yang digunakan adalah : Polybag, ukuran 17 x $7 \mathrm{~cm}$, Semai Makila (Litsea angulata), Media tanam (Tanah), Paranet $30 \%$, Paranet $50 \%$, Paranet $65 \%$, Paranet $75 \%$.

\section{Prosedur Penelitian.}

\section{Persiapan Media Tanah}

Media Tanama (Tanah) yang di gunakan adalah seragam yaitu berupa jenis tanah rigosol yang diisi pada pollybag.

\section{Persiapan Semai}

Semai yang di gunakan pada penelitian adalah semai asal cabutan yang diambil di Desa Kawa Kabupaten Seram Bagian Barat. Semai diambil dari beberapa pohon induk dengan umur yang sama ditandai dengan tinggi, jumlah daun dan mempunyai diameter yang seragam. Untuk mengindari gangguan fisologis disaat pengangkutan,setelah diambil, semai 
packing sedemikian rupa sehingga tidak layu dan kering. semai diambil langsung ditanam pada media yang sudah disiapkan

\section{Naungan}

Semua semai yang telah disiapkan kemudian ditempatkan pada paranet yang berbeda yang" " terdiri dari $30 \%, 50 \%, 65$ $\%, 75 \%$, dan ditempat yang terbuka. jumlah semai yang digunakan tiap perlakuan adalah 10 semai dengan ulangan tiga kali. jumlah kebutuhan semai untuk penelitian ini adalah $10 \times 3 \times 5=150$

\section{Pemeliharaan}

Pemeliharaan semai dalam naungan terdiri atas :

\section{- Penyiraman}

Penyiraman adalah salah satu hal yang penting dalam naungan karena tumbuhan pada umur ini memerlukan air yang cukup banyak. Kemudian penyiraman dilakukan satu hari dua kali yaitu pagi dan sore hari dengan volume air yang sama.

\section{- Penyiangan}

Penyiangan dilakukan yaitu dengan membersikan gulma yang tumbuh disekitar semai.

\section{Parameter Yang Diukur}

1. Tinggi

Semai akan diukur mulai dari leher akar sampai ke pucuk.
2. Diameter

Diameter semai diukur mulai dari $10 \mathrm{~cm}$ mulai dari leher akar.

\section{Jumlah Daun}

Daun yang diukur pada semai adalah daun yang terbuka penuh.

4. Berat kering tanaman

Berat kering tanaman diukur pada saat akhir pengamatan dengan mencabut beberapa jenis (Periodik) masing-masing perlakuan untuk dikeringkan pada oven.

\section{Rancangan Percobaan}

Dalam pelaksanaan penelitian ini digunakan rancangan acak lengkap dengan menggunakan 5 perlakuan yaitu :

A0 : Tanpa naungan

A1 : $30 \%$

A3 : $50 \%$

A $4: 65 \%$

A5 : $75 \%$

Masing-masing perlakuan diulangi sebanyak 3 kali, dan setiap ulangan digunakan 30 anakan dengan demikian total keseluruhan 150 anakan, dengan mengggunakan rumus matematika (Anonim, 2007).

$\mathrm{Yij}=\mu+\mathrm{Pi}+\sum \mathrm{ij}$

Dimana :

Yij = Pengamatan perlakuan ke-I dan ulangan ke-j

$\mathrm{Pi}=$ Pengaruh perlakuan ke-i

$\sum \mathrm{ij}=$ Galat perlakuan ke-I dan ulangan ke-j 
Analisis Data

Hasil pengukuran tinggi, diameter, jumlah daun presentase hidup tanaman dengan analisis keragaman. Jika hasil tiap tingkat berpengaruh nyata, maka akan dilanjutkan dengan menggunakan dengan uji beda nyata jujur (BNJ).

\section{HASIL DAN PEMBAHASAN}

\section{Pertambahan Diameter Makila (Litsea angulata)}

Hasil penelitian menunjukan bahwa besarnya pertambahan diameter semai makila (Litsea angulata) berkisar antara $1 \mathrm{~mm}$ sampai dengan 1,25 $\mathrm{mm}$. Hasil rata-rata pertambahan diameter semai makila (L. angulata) pada semai yang menggunakan naungan 50 persen adalah $1 \mathrm{~mm}$, tanpa naungan $1,13 \mathrm{~mm}$, naungan 30 persen $1,4 \mathrm{~mm}$, Naungan 75 persen 1,4 mm, dan Naungan 65 persen $1,25 \mathrm{~mm}$

Hasil pertumbuhan diameter di tiap-tiap naungan dapat dilihat pada Tabel 1 .

Tabel 1. Rata-rata Pertambahan Diameter Semai Makila (Litsea angulata)

\begin{tabular}{cccccc}
\hline \multicolumn{7}{c}{ Perlakuan } & $\begin{array}{c}\text { Tanpa } \\
\text { Naungan }\end{array}$ & $\mathbf{3 0} \%$ & $\mathbf{5 0} \%$ & $\mathbf{6 5} \%$ & $\mathbf{7 5} \%$ \\
\hline I & 1,3 & 1,3 & 1,4 & 0,4 & 1,4 \\
II & 0,5 & 1,6 & 0,4 & 1,3 & 1,3 \\
III & 1,6 & 1,3 & 1,2 & 2,07 & 1,5 \\
\hline Total & $\mathbf{3 , 4}$ & $\mathbf{4 , 2}$ & $\mathbf{3}$ & $\mathbf{3 , 7 7}$ & $\mathbf{4 , 2}$ \\
\hline Rata-rata & $\mathbf{1 , 1 3} \mathbf{~ m m}$ & $\mathbf{1 , 4} \mathbf{~} \mathbf{m}$ & $\mathbf{1} \mathbf{~} \mathbf{m}$ & $\mathbf{1 , 2 5} \mathbf{~ m m}$ & $\mathbf{1 , 4} \mathbf{~ m m}$ \\
\hline
\end{tabular}

Pada Tabel 1 diatas terlihat bahwa besar diameter semai makila pada tiap-tiap naungan sangat berbeda. Hal ini disebabkan karena adanya hubungan yang erat antara pertumbuhan tanaman dengan ketersediaan cahaya pada tiap-tiap naungan. Setiap tumbuhan membutukan cahaya yang berbeda-beda dalam pertmbuhannya karena dapat membantu dalam proses fotosintesis. Menurut
Toumey dan Korstia (1974) dalam Simarangkir (2000) pertumbuhan diameter tanaman berhubungan erat dengan laju fotosintesis akan sebanding dengan jumlah intensitas cahaya matahari yang diterima dari respirasi. Akan tetapi pada titik jenuh cahaya, tanaman tidak mampu menambah hasil fotosintesis walaupun jumlah cahaya bertambah. Selain itu produk fotosintesis sebanding dengan total luas daun aktif 
yang dapat melakukan fotosintesis. Pernyataan Daniel et al,(1992) bahwa terhambatnya pertumbuhan diameter tanaman karena produk fotosintesisnya serta spektrum cahaya matahari yangkurang merangsang aktivitas hormon dalam proses pembentukan sel meristematik kearah diameter batang, terutama pada intensitas cahaya yang rendah.

Pada umumnya cahaya yang diperlukan oleh setiap jenis tanaman berbeda-beda, Suatu tanaman dikatakan bertumbuh apabila mengalami pertambahan diameter dan juga tinggi. Proses pertumbuhan ini berjalan secara berangsur-angsur. Demikian juga dengan pertambahan diameter tanaman makila. Proses ini terjadi sebagai akibat dari pembelahan sel-sel kambium untuk memproduksi sel-sel kayu yang berdinding tebal dan berliknin (xylem) pada suatu sisi dan lapisan berdinding tipis (Daniel $d k k, 1979)$.

\section{Pertambahan Tinggi Makila (Litsea angulata)}

Hasil penelitian menunjukan bahwa besarnya pertambahan tinggi semai makila (Litsea angulata) berkisar antara 1,5 cm mm sampai dengan 1,9 cm. Hasil rata-rata pertambahan diameter semai makila (L. angulata) pada semai yang tanpa menggunakan naungan $1,5 \mathrm{~cm}$, naungan 30 persen $1,48 \mathrm{~cm}$, Naungan 75 persen 1,63 cm, Naungan 50 persen 1,76 $\mathrm{cm}$,dan Naungan 65 persen $1,9 \mathrm{~cm}$. Pertambahan tinggi semai dapat dilihat pada Tabel 2

Tabel 2. Rata-rata Pertambahan Tinggi Semai Makila (Litsea angulata)

\begin{tabular}{cccccc}
\hline \multirow{2}{*}{ Perlakuan } & $\begin{array}{c}\text { Tanpa } \\
\text { Naungan }\end{array}$ & $\mathbf{3 0} \%$ & $\mathbf{5 0} \%$ & $\mathbf{6 5} \%$ & $\mathbf{7 5} \%$ \\
\hline I & 1,7 & 2,6 & 2,9 & 1 & 1,8 \\
II & 2 & 1 & 1,5 & 1,8 & 1,6 \\
III & 0,8 & 0,8 & 0,9 & 2,9 & 1,5 \\
\hline Total & $\mathbf{4 , 5}$ & $\mathbf{4 , 4 4}$ & $\mathbf{5 , 3}$ & $\mathbf{5 , 7}$ & $\mathbf{4 , 9}$ \\
\hline Rata-rata & $\mathbf{1 , 5} \mathbf{~ c m}$ & $\mathbf{1 , 4 8} \mathbf{~ c m}$ & $\mathbf{1 , 7 6} \mathbf{~ c m}$ & $\mathbf{1 . 9} \mathbf{~ c m}$ & $\mathbf{1 , 6 3} \mathbf{~ c m}$ \\
\hline
\end{tabular}

Pada Tabel 2 diatas terlihat bahwa makila dengan diameter terbesar juga memiliki pertumbuhan tinggi yang baik . Pertambahan tinggi tanaman terjadi akibat pembelahan meristem ujung yang menghasilkan sel-sel baru di ujung akar atau batang (Gardner, dkk 1991). Bembelahan sel terjadi karena atas bantuan 
cahaya matahari, Soekotjo (1976) dalam Simarangkir (2000) berpendapat bahwa pengaruh cahaya terhadap pembesaran sel dan diferensiasi sel berpengaruh terhadap pertumbuhan tinggi, ukuran daun serta batang.

\section{Pertambahan Jumlah Daun Makila (Litsea angulata)}

Hasil penelitian menunjukan bahwa jumlah pertambahan daun semai makila (Litsea angulata) berkisar antara
2,66 helai sampai dengan 4,66 helai. Hasil rata-rata pertambahan jumlah daun semai makila (Litsea angulata) pada semai yang menggunakan naungan 30 persen 2,66 helai, tanpa naungan 3 helai, naungan 50 persen 4 helai, naungan 56 persen 4,66 helai. Hasil pertambahan jumlah daun semai di tiap-tiap naungan dapat dilihat pada Tabel 3.

Tabel 3. Rata-rata Pertambahan Jumlah Daun Semai Makila (Litsea angulata)

\begin{tabular}{cccccc}
\hline \multirow{2}{*}{ Perlakuan } & $\begin{array}{c}\text { Nanpa } \\
\text { Naungan }\end{array}$ & $\mathbf{3 0} \%$ & $\mathbf{5 0} \%$ & $\mathbf{6 5} \%$ & $\mathbf{7 5} \%$ \\
\hline I & 2 & 2 & 3 & 6 & 3 \\
II & 3 & 3 & 4 & 5 & 7 \\
III & 4 & 3 & 5 & 3 & 1 \\
\hline Total & $\mathbf{9}$ & $\mathbf{8}$ & $\mathbf{1 2}$ & $\mathbf{1 4}$ & $\mathbf{1 1}$ \\
\hline Rata-rata & $\mathbf{3}$ & $\mathbf{2 , 6 6}$ & $\mathbf{4}$ & $\mathbf{4 , 6 6}$ & $\mathbf{3 , 6 6}$
\end{tabular}

Pada Tabel 3 diatas sangat terlihat perbedaan jumlah daun pada naungan yang di gunakan dengan tiap-tiap taraf perlakuan. Kramer dan Kozlowski (1979) mengemukakan bahwa klorofil dan karatenoidter dapat banyak pada jaringan helaian daun, termasuk tangkai daun dan tunas. Di dalam daun, cahaya akan diserap oleh molekul klorofil untuk dikumpulkan pada pusat-pusat reaksi. Pada tumbuhan ada dua jenis pigmen yang berfungsi aktif sebagai pusat reaksi atau fotosistem yaitu fotosistem II dan fotosistem I. Fotosistem
II terdiri dari molekul klorofil yang menyerap cahaya dengan panjang gelombang 680 nanometer, sedangkan fotosistem I 700 nanometer.

Fitter dan Hay (1992) dalam Marjenah (2001) mengemukakan bahwa jumlah luas daun menjadi penentu utama kecepatan pertumbuhan. Keadaan seperti ini dapat dilihat pada hasil penelitian dimana daun-daun yang mempunyai jumlah luas daun yang lebih besar mempunyai pertumbuhan yang besar pula. Dalam pengamatan yang dilakukan daun- 
daun semai di bawah naunganpohon mempunyai warna yang lebih gelap dibandingkan pada tempat terbuka .Hal ini diduga bahwa daun-daun yang ternaung mempunyai jumlah klorofil yang lebih banyak. Marjenah (2001) mengemukakan ditempat terbuka mempunyai kandungan klorofil lebih rendah dari pada tempat ternaung. Pertambahan daun juga sangat dipegaruhi oleh besaran cahaya yang cukup pada semai yang ada pada umur yang muda

Penaung mengakibatkan perubahan terhadap cahaya matahari yang diterima tanaman, baik intensitas maupun kualitasnya. Pengaruh cahaya terhadap tanaman sangat kompleks, yaitu mempengaruhi proses fotokomia dan juga bentuk dan ukuran tanaman, sehingga akan berpengaruh terhadap hasil akhir tanaman(Woodward dan Sheely. 1983; dalam Sundari 2005).

Pemberian naungan pada tanaman baik secara alami dan buatan akan berarti mengurangi intensitas cahaya yang diterima oleh tanaman tersebut, hal ini akan mempengaruhi pertumbuhan maupun hasil tanaman. Tanaman yang kurang mendapatkan cahaya matahari akan mempunyai akar yang pendek, cahaya matahari penuh yang menghasilkan akar lebih panjang dan lebih bercabang (Darmajaya, 2008).

Setiap tanaman atau jenis pohon mempunyai toleransi yang berlainan terhadap cahaya matahari. Ada tanaman yang tumbuh baik ditempat terbuka sebaliknya ada beberapa tanaman yang dapat tumbuh dengan baik pada tempat teduh/bernaungan. Ada pula tanaman yang memerlukan intensitas cahaya yang berbeda sepanjang periode hidupnya. Pada waktu masih muda memerlukan cahaya dengan intensitas rendah dan menjelang sapihan mulai memerlukan cahaya dengan intensitas tinggi (Soekotjo,1976 dalam Faridah, 1995).

Sebagian dari jenis-jenis Dipterocarpaceae terutama untuk jenis kayu yang mempunyai berat jenis tinggi atau tenggelam dalam air atau sebagian lagi tergolong jenis semi toleran atau gap appertunist yaitu jenis-jenis yang memiliki kayu terapung atau berat jenis rendah. Kebutuhan cahaya untuk pertumbuhannya diwaktu muda (tingkat anakan) berkisar antara 50 - $85 \%$ dari cahaya total 
Tabel 4. Rata-rata Pertambahan Diameter Semai Makila

\begin{tabular}{cccccc}
\hline & \multicolumn{5}{c}{ Perlakuan } \\
\cline { 2 - 6 } Ulangan & $\mathbf{N 0}(\mathbf{0} \%)$ & $\mathbf{N 1}(\mathbf{3 0} \%)$ & $\mathbf{N 2}(\mathbf{5 0} \%)$ & $\mathbf{N 3}(\mathbf{6 5} \%)$ & $\mathbf{N 4}(\mathbf{7 5} \%)$ \\
\hline I & 1.30 & 1.30 & 1.40 & 0.40 & 1.40 \\
II & 0.50 & 1.60 & 0.40 & 1.30 & 1.30 \\
III & 1.60 & 1.30 & 1.20 & 2.07 & 1.50 \\
\hline
\end{tabular}

Tabel 5. Analisis Ragam Diameter Semai Makila

\begin{tabular}{ccccccc}
\hline Sumber & Derajat & Jumlah & Kuadrat & F & \multicolumn{2}{c}{ F Tabel } \\
keragaman & bebas & Kuadrat & Tengah & Hitung & $\mathbf{0 , 0 5}$ & $\mathbf{0 , 0 1}$ \\
\hline Perlakuan & 4 & 0.36 & 0.0903267 & 0.3365459 & & \\
Galat & 10 & 2.68 & 0.2683933 & & $\mathbf{3 . 4 8}$ & $\mathbf{5 . 9 9}$ \\
Total & 14 & 3.05 & & & & \\
\hline
\end{tabular}

Dari hasil rata-rata pertambahan semai makila pada Tabel 4 selama tiga bulan menunjukan bahwa diantara 5 taraf perlakuan dengan 3 ulangan dan analisis keragaman pada tabel 5 menunjukkan hasil tidak berpengaruh nyata, jika dibandikan hasil pertambahan rata-rata antara perlakuan tanpa menggunakan naungan dengan perlakuan lainya dengan menggunakan naungan, hal ini disebakan karena semai makila (Litsea angulata) dapat bertumbuh pada keadaan tempat yang tertutup dan juga sebaliknya pada tempat yang terbuka. Selain dari itu penyebab terjadinya hasil penelitian tidak berpengaruh nyata adalah karena angka cura hujan pada saat penelitian turut berpengaruh sehingga semai makila ( $L$. angulata) baik yang berada dalam naungan maupun tanpa menggunakan naungan menunjukan hasil yang sama.

Tabel 6. Rata-rata Pertambahan Tinggi Semai Makila

\begin{tabular}{cccccc}
\hline & \multicolumn{5}{c}{ Perlakuan } \\
\cline { 2 - 6 } Ulangan & $\mathbf{N 0}(\mathbf{0} \%)$ & $\mathbf{N 1}(\mathbf{3 0} \%)$ & $\mathbf{N 2}(\mathbf{5 0} \%)$ & $\mathbf{N 3}(\mathbf{6 5} \%)$ & $\mathbf{N 4}(\mathbf{7 5} \%)$ \\
\hline I & 1.70 & 2.60 & 2.90 & 1.00 & 1.80 \\
II & 2.00 & 1.00 & 1.50 & 1.80 & 1.60 \\
III & 0.80 & 0.80 & 0.90 & 2.90 & 1.50 \\
\hline
\end{tabular}

Tabel 7. Analisis Ragam Diameter Semai Makila

$\begin{array}{ccccccc}\begin{array}{c}\text { Sumber } \\ \text { keragaman }\end{array} & \begin{array}{c}\text { Derajat } \\ \text { bebas }\end{array} & \begin{array}{c}\text { Jumlah } \\ \text { Kuadrat }\end{array} & \begin{array}{c}\text { Kuadrat } \\ \text { Tengah }\end{array} & \begin{array}{c}\text { F } \\ \text { Hitung }\end{array} & \text { F Tabel } \\ & & & & \mathbf{0 , 0 5} & \mathbf{0 , 0 1}\end{array}$




\begin{tabular}{ccccccc}
\hline Perlakuan & 4 & 0.40 & 0.099333 & 0.148259 & $\mathbf{3 . 4 8}$ & $\mathbf{5 . 9 9}$ \\
Galat & 10 & 6.70 & 0.67 & & & \\
Total & 14 & 7.10 & & & & \\
\hline
\end{tabular}

Tabel 6 menunjukkan hasil ratarata pertambahan tinggi semai selama tiga bulan dan pada tabel 7 adalah analisis ragam diameter semai makila yang menunjukan hasil yang tidak nyata. Hal ini disebabkan karena semai makila (Litsea angulata) dapat bertumbuh pada keadaan tempat yang tertutup dan juga sebaliknya pada tempat yang terbuka. Selain dari itu penyebab terjadinya hasil penelitian tidak berpengaruh nyata adalah karena angka cura hujan pada saat penelitian turut berpengaruh sehingga semai makila ( $L$. angulata) baik yang berada dalam naungan maupun tanpa menggunakan naungan menunjukan hasil yang sama.

Menurut Dendrobium dkk (2005) meskipun adanya taraf naungan yang berbeda, cahaya matahari masih dapat menyinari tanaman karena cahaya matahari mempunyai panjang gelombang yang berbeda-beda sesuai dengan kebutuhan tanaman untuk fotosintesis. Proses fotosintetik, klorofil hanya menangkap sinar merah dan sinar biruviolet saja yang dibagi menjadi dua sistem, fotosintesis I yang diaktifkan oleh cahaya merah jauh (680-700 nm) dan fotosintesis II diaktifkan oleh cahaya merah $(650 \mathrm{~nm})$.

Tabel 8. Rata-rata Pertambahan Jumlah Daun Semai Makila

\begin{tabular}{cccccc}
\hline & \multicolumn{5}{c}{ Perlakuan } \\
\cline { 2 - 6 } Ulangan & $\mathbf{N 0}(\mathbf{0} \%)$ & $\mathbf{N 1}(\mathbf{3 0} \%)$ & $\mathbf{N 2}(\mathbf{5 0} \%)$ & $\mathbf{N 3}(\mathbf{6 5} \%)$ & $\mathbf{N 4}(\mathbf{7 5} \%)$ \\
\hline I & 2.00 & 2.00 & 3.00 & 6.00 & 3.00 \\
II & 3.00 & 3.00 & 4.00 & 5.00 & 7.00 \\
III & 4.00 & 3.00 & 5.00 & 3.00 & 1.00 \\
\hline
\end{tabular}

Tabel 9. Analisis Ragam Jumlah Daun Semai Makila

\begin{tabular}{ccccccc}
\hline $\begin{array}{c}\text { Sumber } \\
\text { keragaman }\end{array}$ & $\begin{array}{c}\text { Derajat } \\
\text { bebas }\end{array}$ & $\begin{array}{c}\text { Jumlah } \\
\text { Kuadrat }\end{array}$ & $\begin{array}{c}\text { Kuadrat } \\
\text { Tengah }\end{array}$ & $\begin{array}{c}\text { F } \\
\text { Hitung }\end{array}$ & \multicolumn{2}{c}{ F Tabel } \\
\hline Perlakuan & 4 & 7.60 & 1.9 & 0.678571 & $\mathbf{3 . 4 8}$ & $\mathbf{0 , 0 1}$ \\
Galat & 10 & 28.00 & 2.8 & & & \\
Total & 14 & 35.60 & & & & \\
\hline
\end{tabular}


Jika dilihat pada Tabel 8 hasil ratarata pertambahan jumlah daun dan hasil analisis ragam pada tabel 9 pada penelitian selama tiga bulan tidak menunjukkan perbedaan nyata jika dibandingan dengan taraf perlakuan lainnya, hal ini disebabkan karena semai makila pada umumnya dapat bertumbuh pada tempat terbuka dan tempat yang ternaung selain dari itu penyebab tidak terjadinya perbedaan nyata dikarenaka angka cura hujan selama

\section{Indeks Mutu Bibit (IMB)}

penelitian turut berpengaruh pada semai didalam naungan. Menurut penelitian Widiastoety dan Bahar (1995), penggunaan naungan yang akan memberikan intensitas cahaya sebesar $75 \%$, 65\% dan 55\% sama baiknya bagi pertumbuhan tinggi tanaman, jumlah daun dan panjang daun serta pertambahan/pembentukan tunas. Selain dari itu, iklim sangat berpengaruh penting dalam roses persemaian karena pada saat penelitian terjadi curah hujan sangat besar.

Tabel 10. Rata-rata Indeks Mutu Bibit

\begin{tabular}{llllll}
\hline Perlakuan & & & & & \\
Ulangan & N0 $(0 \%)$ & N1 $(30 \%)$ & N2 $(50 \%)$ & N3 $(65 \%)$ & N4 (75 \%) \\
\hline I & $\mathbf{0 , 3 3 0}$ & $\mathbf{0 , 2 1 1}$ & $\mathbf{0 , 2 4 9}$ & $\mathbf{0 , 2 1 3}$ & $\mathbf{0 , 1 3 5}$ \\
II & $\mathbf{0 , 1 7 9}$ & $\mathbf{0 , 2 5 2}$ & $\mathbf{0 , 3 6 6}$ & $\mathbf{0 , 1 4 9}$ & $\mathbf{0 , 1 8 2}$ \\
III & $\mathbf{0 , 7 5 2}$ & $\mathbf{0 , 2 7 7}$ & $\mathbf{0 , 1 4 7}$ & $\mathbf{0 , 2 1 4}$ & $\mathbf{0 , 2 3 0}$ \\
\hline
\end{tabular}

Tabel 11. Analisis Ragam Indeks Mutu Bibit

\begin{tabular}{|c|c|c|c|c|c|c|}
\hline \multirow{2}{*}{$\begin{array}{l}\text { Sumber } \\
\text { keragaman }\end{array}$} & \multirow{2}{*}{$\begin{array}{l}\text { Derajat } \\
\text { bebas }\end{array}$} & \multirow{2}{*}{$\begin{array}{l}\text { Jumlah } \\
\text { Kuadrat }\end{array}$} & \multirow{2}{*}{$\begin{array}{l}\text { Kuadrat } \\
\text { Tengah }\end{array}$} & \multirow{2}{*}{$\begin{array}{l}\text { F } \\
\text { Hitung }\end{array}$} & \multicolumn{2}{|c|}{ F Tabel } \\
\hline & & & & & 0,05 & $\mathbf{0 , 0 1}$ \\
\hline Perlakuan & 4 & 109 & $\mathbf{0 , 0 2 7}$ & 1,29 & 3,478 & 5,994 \\
\hline Galat & 10 & 0,210 & 0,021 & & & \\
\hline Total & 15 & 319 & & & & \\
\hline
\end{tabular}

Tabel 10 diatas menunjukkan perhitungan rata-rata Indeks Mutu Bibit dan pada tabel 11 adalah analisis ragam Indeks Mutu Bibit (IMB), walaupun setelah melakukan perhitungan beberapa parameter yang di ukur secara statistik tidak menunjukan perbedaan nyata pada setiap taraf perlakuan, maka akan dilakukan perhitungan rata-rata Indeks Mutu Bibit sebagai salah satu indikator yang baik dan siap di tanam. Perhitungan rata-rata Indeks Mutu Bibit (IMB) dapat dilihat pada Tabel 12 .

Tabel 12. Rata-rata Perhitungan Indeks Mutu Bibit Pada Tiap-Tiap Naungan.

\begin{tabular}{llllll}
\hline Perlakuan & Tanpa Naungan & $30 \%$ & $\mathbf{5 0} \%$ & $\mathbf{6 5} \%$ & $\mathbf{7 5} \%$ \\
\hline
\end{tabular}


Pada Tabel 12 menunjukan bahwa IMB bekisar antara 0,38 sampai dengan 0,787 dengan hasil rata-rata adalah perlakuan dengan menggunakan naungan 30 persen 0,38,tanpa menggunakan naungan 0,268 ,naungan 75 persen 0,365 ,naungan 30 persen 0,369 dan naungan 65 persen 0,787 . Tingginya berat kering total akan mempengaruhi IMB , artinya bahwa semakin tinggi berat kering total maka semakin tinggi juga IMB pada suatu perlakuan. Hal ini dikemukakan oleh Heriyanto dan Siregar (2004) menyatakan bahwa Indeks Mutu Bibit dipengaruhi oleh berat kering total,semakin besar nilai berat kering totalnya maka semakin tinggi angka indeks mutu bibitnya. Martin et al (2004) juga mengemukakan bahwa tanaman yang siap ditanam di lapangan memiliki indeks mutu bibit 0,09 karena nilai tersebut mempunyai kemampuan tumbuh di lapangan. Jika di lihat dari hasil perhitungan rata-rata Indeks Mutu Bibit maka semua perlakuan dapat dinyatakan tumbuh di lapangan .

\section{KESIMPULAN}

1. Berdasarkan hasil penelitian semai makila (Litsea angulata) pada tiap-tiap taraf perlakuan tidak menunjukan perbedaan yang nyata
2.Hasil peneliatan menunjukan bahwa semai makila (Litsea angulata) dapat bertumbuh pada keadaan tempat yang tertutup.

\section{DAFTAR PUSTAKA}

Anonim, 2007. Rancangan Acak Lengkap (RAL) http://staff.unud.ac .id

Anggelina fiona, 2008. Faktor yang mempengaruhi Pertumbuhan Tumbuhan.

http://Fionaanggelina.com (diakses 28 agustus 2014)

Anonim, 1981. Mengenai sifat-sifat kayu indonesia dan penggunaanya. Kanisius, Yogyakarta

Daniel T. W, J.A. Helms and F.S. Baker, 1992. Prinsip-Prinsip Silvikultur (Terjemahan). Gadjah Mada University Press. Yogyakarta
Darmajaya. 2008. Kemampuan $\mathrm{T}_{\dot{c}} \mathrm{a}$ Menyerap Cahaya. Universitas Gadja Mada. Yogyakarta.

Dendrodium, 2005. Pengaruh Media Tumbuh Aklimatisasi dan Jenis

Faridah E, 1995. Pengaruh Intensitas Cahaya, Mikoriza Dan Serbuk Arang Pada Pertumbuhan Alam Drybalanops Sp Buletin Penelitian Nomor 29. Fakultas Kehutanan Universitas Gadjah Mada Yogyakarta. 
Gardner, Pearce and Mitchell. 1991. Fisiologi Tanaman. Indonesia.Jakarta

halaman.Www.silvikultur.com/pengaruh caha ya tanaman.html

Kramer P. J. and T. T. Kozlowski, 1979. Physiology of Woody Plants. Academic Press, Inc. Florida.

Marjenah, 2001. Pengaruh Perbedaan Naungan di Persemaian Terhadap Pertumbuhan dan Respon Morfologi Dua Jenis Semai Meranti. Jurnal Ilmiah Kehutanan "Rimba Kalimantan" Vol. 6. Nomor. 2. Samarinda. Kalimantan Timur.

Martin E, Islam S, Rahmat T. 2004. Pengaruh Endomikoriza dan Media Semai Terhadap Pertumbuhan Pulai, Bungur, Mangium dan Sungkai di Persemaian . Jurnal Penelitian Hutan Tanaman

Marjenah, 2001. Pengaruh Perbedaan Naungan di Persemaian Terhadap Pertumbuhan dan Respon Morfologi Dua Jenis Semai Meranti. Jurnal Ilmiah Kehutanan "Rimba
Kalimantan” Vol. 6. Nomor. 2. Samarinda. Kalimantan Timur.

Marsono, (1999). Fonetik. Yogyakarta. Gaja Mada University Poerwowidodo, 1992. Telaah Kesuburan Tanah. Angkasa. Bandung

Simarangkir B.D.A.S, 2000. Analisis Riap Dryobalanopslanceolata Burck pada Lebar Jalur yang Berbeda di Hutan Koleksi Universitas Mulawarman Lempake. Frontir Nomor 32. Kalimantan Timur.

Suhardi, 1995. Effect Of Shading, Mycorrhiza Inoculated And Organic Matter On The Growth Of Hopea Gregaria Seedling Buletin Penelitian Nomor 28. Fakultas Kehutanan Universitas Gadjah Mada Yogyakarta.

Sundari T. 2005. Keragaan Hasil Dan Toleransi Genotipe Kacang Hijau Terhadap Penaungan.

Theodore W. Daniel,John A. Helms and Frederick S. Baker. 1979. PrinsipPrinsip Silvikultur Edisi Kedua. Gajamada University Press. Jogjakarta 